\title{
Maintaining peak performance as an elite Paralympian
}

\author{
Bo Hedges
}

\section{BASKETBALL BEGINNINGS}

I first started playing when I was 13 when my hometown got some wheelchairs and started a team. I know a lot of guys who are 10 years older than myself whose shoulders were pretty shot by the time they were 45 , because all they did was push and push and did no counterbalance work. Being a daily wheelchair user, as well as playing wheelchair sport, that wear and tear is continuous and ongoing on the shoulders and the joints.

Trying to balance all of that while still playing becomes harder and harder over the years and the presence of a balanced workout becomes more important. When I first started playing wheelchair basketball, it was about learning how to train to be able to compete at the highest level with the best players in the world. As I have gotten older, it is all about training smarter, training with a purpose.

\section{EVOLUTION OF PARASPORT AWARENESS}

There is a lot more knowledge out there about wheelchair athletes now, and a lot of it comes down to just the willingness to try and sometimes, to fail. I have been fortunate to work with people that are willing to learn with you and willing to accept that they may not know everything that there is about working with a disabled athlete. Every disability is different and every athlete is different, whether they are able-bodied or not. So a willingness to learn and work together is huge.

The adaptability of the environment is also important. The lifting environment could definitely challenge a disabled athlete. Building or adapting the environment that they work out in so that they feel comfortable is pretty big. There is a lot more accessible equipment for weight rooms now, so having that there as a starting point for athletes is huge. So maybe they do not have to get out of their chair the first few times they come to the weight room. Over time, if you build their confidence, or as they get to know other athletes that are getting on the regular bench press or getting down on the floor to do things, they may want to challenge themselves to do that too.

\section{THINKING OUTSIDE THE BOX}

There is also a ton of different exercises, especially in the weight room, that can be adapted with some creative thinking to match what an athlete's capabilities are. You do not want to jump to the high-end exercises that you have in mind for them, because their confidence in their abilities might not be there yet. But if you work through a bunch of smaller challenges, then you get to this point where you can challenge them with some sort of core exercise or some sort of advanced exercise technique that you have in mind.

You have to read that athlete's ability and confidence in their abilities, especially with para-athletes. Because as younger athletes come in they are not quite sure of what they can do and you want to get the most out of them.

\section{MAKING THINGS LAST AND UTILISING THE TEAM}

I have been able to play wheelchair basketball in three Paralympic Games and have played competitively for over 20 years (figure 1). My longevity in competitive sport has been enhanced through access to all aspects of the integrated support team (sports science, sport medicine and administrative personnel) and being more open to trying different things. Early in my career, there was not a lot around for support at the national team level. As we went towards Beijing in 2008, and then to London in 2012, it was more readily available for us.

The older I get, it is really about finetuning what I eat and how I eat, especially leading into a competition so that I am in peak form. I started thinking about the nutrition aspect in 2003/2004 and then taking it seriously around 2005 , and that really elevated my ability to perform. I cannot diet all the time, so you have to pace yourself just like it is a training cycle.

The acceptance of what massage and physiotherapy/athletic therapy could do was also important. I am constantly willing to get in there because I know the benefits of it. Injury prevention has changed dramatically since I first started into wheelchair sport, to now where we are continuously working on

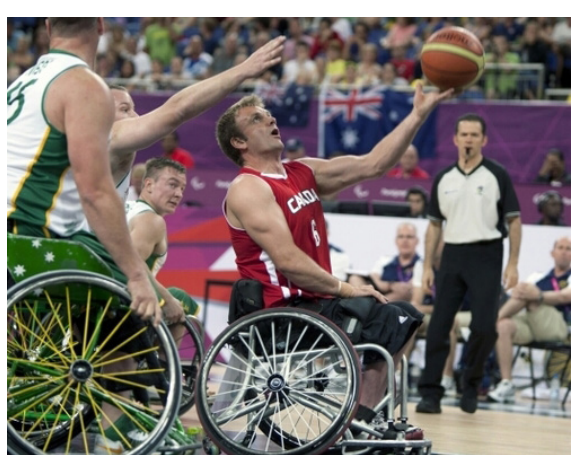

Figure 1

counterbalance through theraband and shoulder stability work.

\section{MENTAL CONSIDERATIONS AS A PARALYMPIAN}

I am still evolving in terms of my ability to calm my mind on the court during the most intense moments. As an athlete you battle anxiety a bit, wondering if you have done enough. It is a challenge to have the confidence level that you need when going out on to the court at a World Championships or Paralympics. Through help with mental training, I am able to remind myself that I have worked as hard as anybody, I have these skills and that I just need to execute.

Work-life balance can also be a mental burden. Time catches up to everybody, right? You have to be prepared to transition out after a career is over, so figuring out a plan weighs on your mental wellbeing. You have to prepare yourself so that, at the end stage of your playing career, you can still focus on basketball without being distracted.

\section{ENGAGING THE COACHING STAFF IN THE PROCESS}

I think embracing the overall approach of the integrated support team is huge. On the court, the coaches typically have a plan. I think that trying to make sure coaches understand the importance of the off-court stuff is pretty big. It is slowly changing, but there are still some old-school coaches out there who feel that more is better, regardless of whether the national championships or the Paralympics are a week away.

You need to recuperate after a hard intense training cycle, so you can have a peak performance. I think working with the coaching staff to understand that is the best way, and itis hoped that the coaching staff are receptive to that. Figuring out a way that you can 
make them receptive to as well is really important.

Three bits of advice for clinicians dealing with wheelchair athletes

1. Be open-minded and observant in the beginning to learn the uniqueness of each person's disability.

2. Do not put limitations on the type and number of exercises someone can use based on their disability.

3. Adaption through trial and error is normal. The athlete and the clinician need to realise this and not get overly frustrated.

Twitter Bo Hedges@therealbohedges

Contributors None declared.

Funding The authors have not declared a specific grant for this research from any funding agency in the public, commercial or not-for-profit sectors.

Competing interests None declared.

Patient consent for publication Obtained.

Provenance and peer review Commissioned; internally peer reviewed.
(C) Author(s) (or their employer(s)) 2020. No commercial re-use. See rights and permissions. Published by BMJ.

$$
\text { A) Check for updates }
$$

To cite Hedges B. Br J Sports Med 2020;54:1062-1063.

Accepted 20 February 2020

Published Online First 27 March 2020

Br J Sports Med 2020;54:1062-1063. doi:10.1136/bjsports-2019-101866

ORCID iD

Bo Hedges http://orcid.org/0000-0002-5493-0911 